\title{
Research on Allocation, and usage of High Quality Education Resources from the Perspective of Fairness and Efficiency
}

\author{
Zhiquan Zhang' ${ }^{1}$, Jieyin ${ }^{2}$
}

Educational science faculty of Nantong University, JiangSu province China 226019

\begin{abstract}
To become powerful human resource country from big human resource country is the strategic target of education development in the next ten years in China. Reasonable disposition and development of high quality education resources is conducive to the realization of this goal. Review evolution of education resource allocation and the problems existed since the founding of the people's Republic of China from the perspective of fairness and efficiency can help us make dialectical thinking and find ways in solving the problems in educational resources allocation and utilization.
\end{abstract}

Keywords: high quality education resources; fairness and efficiency; the siphon effect.

The 17th Chinese communist party Congress proposed "put education development on the priority position in order to make china a powerful nation of human resources." Around this strategy, china formulated "national long term educational reform and development plan (2010-2020)". this plan propose that,"the future development and great rejuvenation of the Chinese nation depend talent and education, so develop high quality education and cultivate excellent talent are the most priority of future Chinese education. In order to realize this aim, china will insist "education must satisfied the need of student, must regard reform and creativity as the power, make fairness realizing and education quality raising as the key and heart. Realizing quality education comprehensively, make china change from a big human resources to a strong human resources country."'If china want to obtain the aims, it must achieve two objectives. One is to cultivate more variety talents. That's to say, china must cultivate all kinds of talents according to the needs and interest of the students and the need of society. Two is to cultivate outstanding talents. More and variety talents can only guarantee the need of society development, but can't guarantee the advanced need of society and the country. So if china wants to be an advanced country, they must try their best to cultivate student with high intelligence into excellent talent and cultivate high intelligent student in different ways. The two objects are not only connected with education fairness, but also connected with educational efficiency. Therefore the key of making china to be a power of human resources is to improve its efficiency of education and the efficient utilization of educational resources. But human's development is different from the growth of other things. General things can only be accelerated through external factors, while human's development acceleration has the characteristics of being powered both from external and internal. That also means human's high quality development not only need rich educational resources, but also need the effort and wisdom of themselves. So if china wants to raise its education quality and cultivate more excellent talents, china not only invest more money in education, but also try its best to make scientific education policy and awaken the potential of teacher and student. Good education condition, scientific policy, teacher and student's potential are all valuable educational resources.

\section{DeFinition OF CONCEPT}

\subsection{High Quality Education Resources}

In "dictionary", resource is interpreted as of "the source of the assets, generally refers to the natural sources." 1"Also Refers to all conditions and foundation when engage in certain activities. Include both material and financial resource, manpower, including time, space, information... In short, all the conditions and the basis that can ensure and promote the normal activities can be regarded as 
resource."2While education resource also called 'educational conditions', contains two level meanings, usually refers to the total manpower, material and financial resources used and also refers to the historical experience of education or information about education. But in my opinion education resource not only refers to outside resource that can help student develop well, but also refer to teacher and student themselves and their inner potential. While to excellent, it not only means excellent under the perspective of comparation, for example, teacher and student's teaching and learning experience which can improve their teaching and learning efficiency. It also means excellent under the perspective of development, that's to say excellent resource that has big space and possibility in progress.

So exploit excellent education resource not only means allocate education resource fairly and scientifically, but also means school, teacher and student uses education resource at hand thoroughly. Also include studying hard in scientific method and exploit their potential thoroughly with wisdom.

\subsection{Fairness and Efficiency}

Fairness means in public area, every citizen in one country have the same right, opportunity in getting or doing something. In order to ensure fairness, both government and individual have their responsibility. The responsibility of the government is to allocate excellent education resource equally and scientifically among citizens and at the same time make scientific policy to guide the usage efficiency. While the responsibility of individual is trying their best with hard work and wisdom to get fairness that should belong to them. Anyone who is too lazy to do anything want to get all kinds of right, opportunity and resource is impossible.

While to efficiency, we will have different understanding from different angles, truly efficiency means that use less resource, labor or energy to get more product and less side product. For example, in china, how to make student get valuable knowledge, good morality, strong body and variety ability without too harmful study (their healthy especially eyesight is harmed a lot) is very important thing for Chinese education to consider.

\section{China's Resource Allocating Evolution under the Perspective of Fairness AND EFFICIENCY}

It is an interesting thing in china in allocating education resource with the consideration of fairness and efficiency. Because when china pay more attention on efficiency, but it helps Implicit justice come. But when china pays more attention on education fairness, it lowed education efficiency. In order to know the reason; let's look back the history of china's education history and its effect.

\subsection{Period of Emphasizing Efficiency and Neglecting Fairness}

In the early days of the founding of the PRC, educational resources are extremely poor. At the national level, fairness and efficiency cannot be equally balanced. Emphasize efficiency means sacrifice of fairness. In the early days of the founding of new China, China began to carry out large-scale economic construction which needed a large number of talents. At that time, china is lack of education resources and all kinds of talents. In order to speed up the cultivation of urgent talent, excellent talent, the central government took the strategy of using limit and scarce educational resources to run city education and especially key schools. Just as Xiaoping Deng said:" we must build key primary school, middle school and university in the city, and put all excellent talent into key university and key middle school." "3hile to education in rural area is neglected and is invested no money. The only attention government paid on rural education is to encourage farmers to use their own money and labor to build school and hire teacher with low education level for their children. the government only sticking posters and shouting the slogan" People's education must be built by the people and for the people." Although, rural education can't be mentioned in the same breath with city education, but because of the hard life in rural area, farmers know there's and their children better future must depend on education. Children in rural area also know that. They studied much harder than children in city. Finally, The result is most key university (about 80\%) students are not from city but from rural area. That's a surprising thing. The government invests no money but get lot of talents 
from rural education. Almost all the rural children who studies in the university works in city after their graduation. That gradually changed the structure of china's population and society, make rural population becomes less and city population becomes more. That tells us a truth, student himself (herself)'s potential is the most valuable resource that need to be opened or exploited.

“Table2-1. The change of ratio between rural and city population ${ }^{4}$

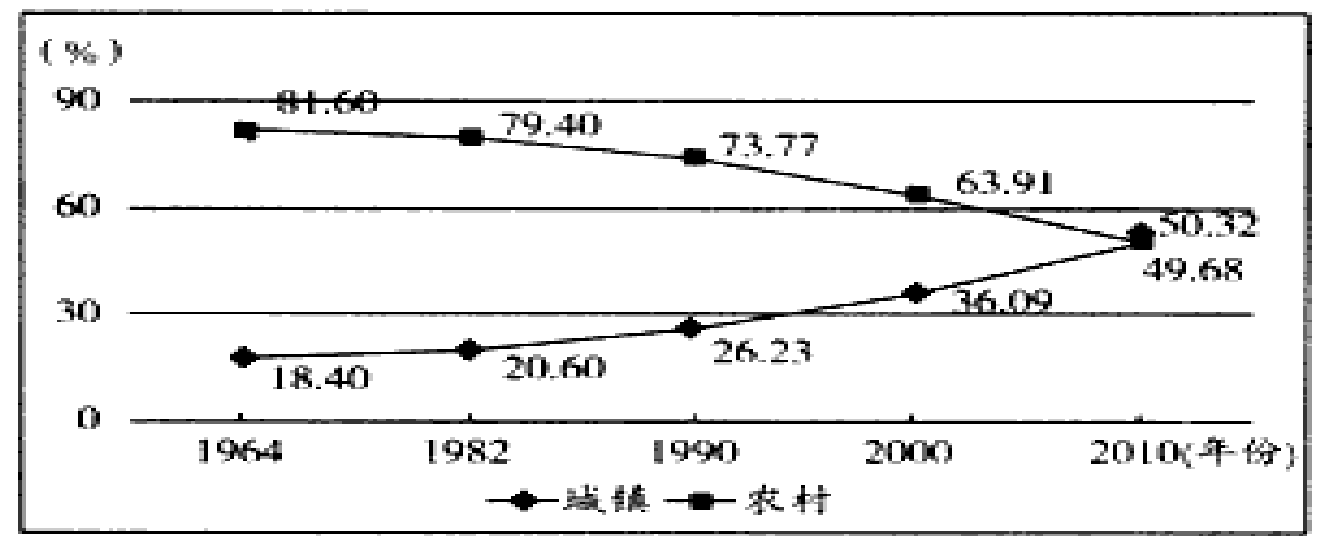

\subsection{Period from Emphasizing Efficiency to Fairness}

When china's economic condition becomes better, the government feel it is time to pay attention to rural education gradually and emphasize education fairness in rural area. The attention reflected in investment. At the beginning, the government not only invest no money in rural education, but also get benefit from rural education, they use the money get from student tuition for other purpose that makes rural student's life harder. Until 2006, the government do not ask student in compulsory student to pay tuition for their education. At the same time, The government gradually decrease the tax the farmers must paid for education and invest more money to build new building for rural primary and middle school. The distance of study condition between rural school and city school becomes smaller and smaller. the change can be seen from the change of education policy.

"China's education reform and development program (issued by CPC Central Committee and the State Council in February 31, 1993)" proposed: "We must exert the initiative of government at all levels, all aspects of the society and the masses in running school, insisting on government's core function in financial allocation, at the same time, encourage multiple channels to raise educational funds" While in December 2005, The State Council sent the notice"On deepening funds guarantee mechanism reform of countryside compulsory education". ${ }^{6}$ From then on, compulsory education is being put into the consideration of public finance guarantee comprehensively. Establish a new Compulsory education funds safeguard mechanism of central and local government share the responsibility according to projects and the ratio. On 1th September 2006, China began to implement "compulsory education law". The newly revised "Compulsory Education Law" finally make clear: "the state will incorporated compulsory education into the scope of financial security fully, funding for compulsory education shall be guaranteed by the State Council and the governments at various levels in accordance with the provisions of this Law "7, From then on, China realized the transform from "People's education by people to People's education by the government." At the same time, the central government make a regulation that all the farmer's children who live in the city with their parents can accept compulsory education without paying any tuition. [10] Just because of that, more and more rural children move in the city school to study, children who study in rural school become less and less. That's weakened compulsory education in rural education. That's an contradiction because when government pay attention to rural education fairness, but weakened rural education, make more and more rural intelligent children leave to study in city. Only those who is taken care of by grandparents and those whose family is too poor to support them to study in city stayed in rural school. Rural schools becomes a place of accepting problem child. Rural education efficiency become lower and lower. 


\section{Exploitation of High Quality Education Resources under the Perspective OF FAIRNESS}

From above description and discussion, we can see that government began to emphasize education fairness in rural area. They think investing more money in rural education and give rural children equal right with city children is a great progress of china's society. But they do not realize what they have done destroyed education ecology of rural area. So when rural school condition has been improved, the government, school, teacher and even students themselves must find ways to exploit the potential of all children. They all have their different responsibilities in exploiting child's potential.

\subsection{The Responsibility of the Government}

The biggest problem exist in china's education is the government interfere education too much, that make the whole country use much money to cultivate similar talent without considering the child's interest and health. That's not only a waste of property of a country, but also a waste of child's life. So the government responsibility is not to interfere educational activity too much, but to make scientific policy to encourage all kinds of schools and family to cultivate child according to their interest and potential. By doing so, the whole country can use less money to cultivate more variety talents.

\subsection{The Responsibility of School Headmaster and Teacher}

All school headmasters and teachers must have their own idea on how to cultivate child into excellent talents according their own interest. So every school and teacher must find suitable education for every child. That needs school and teacher to know the need of the society and the need of every child by investigation and dialogue between students, and families. At the same time, the teacher himself must try his(her) best to get more knowledge and proficient skill so that they have the qualification and ability to cultivate their student.

\subsection{The Responsibility of Student Himself}

A student develop well or bad is decided not only by education (school and family education), but also by student himself. That's to say student's attitude, motivation, diligence are important factors that can ensure student's good development. So student must try their best to use their own potential, wisdom, educational resource around them to promote themselves' development. A lot of excellent talents' development proved that student can have a good development through their diligence though education condition and level is not so good. But in china it must be built on the condition that education should give young student enough freedom and time for them to develop themselves according to their own willing and interest because in china class teaching education and homework occupy students' so much time that students don't have time to develop themselves according to their own willingness.

All in all, students' excellent development is the heart of educational activity, all the action must be taken to make student develop well and happily and all the barriers should be moved away from the path of student's development.

\section{REFERENCES}

[1] Zhengnong, Xia, zhili Chen . lexicon [Z]. Zhong hua press, 2009

[2] GongMei Wu., Compulsory education phase on high quality education resources allocation problem research [D]. Guangxi normal university, 2010:3.

[3] Zhenguo yuan. discussion on the transition of China's education policy - a case study of equality and efficiency of key middle in China [M]. Guangzhou: Guangdong education publishing house, 1999.

[4] http://www.mofangge.com/html/qDetail/08/g3/201112/ufoag308126355.html

[5] GongMei Wu., Compulsory education phase on high quality education resources allocation problem research [D]. Guangxi normal university, 2010:3. 
[6] The China education reform and development outline of the party's central committee and the state council issued in February 1993, 31.

[7] The compulsory education law take effect on September 1, 2006.

\section{AUTHORS' BIOGRAPHY}

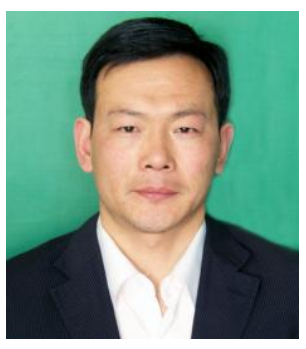

Zhiquan zhang (1972-), male, born in Yanzhou county Shandong province, China. vice professor in educational science of Nantong university, post graduate tutor, post doctor, research on educational principle theory.TL:13814717635. zzhq110@sina.com

Jieyin (1993- ) male, born in Nan Tong city, postgraduate, studying educational principle theory in educational faculty in Nantong University.

This article is the achievement of the National Science Education 1025 planning key project: excellent teacher training effectiveness "value-added" evaluation research, approval number: DIA150318 